\title{
Numerical evaluation of dynamic response of an experimentally tested base-isolated and fixed-base steel structure model
}

\author{
T. Falborski, T. Jaroszewski \& R. Jankowski \\ Faculty of Civil and Environmental Engineering, Gdańsk University of Technology, Gdańsk, Poland
}

\begin{abstract}
Seismic isolation is recognized as one of the most popular and effective methods of protecting structures during earthquake. The present paper is focused on the comparison between the dynamic responses of buildings with fixed and isolated bases exposed to seismic excitations. The aim of the study is to investigate the effectiveness of a simplified base isolation numerical modelling technique using the linear springs. One-storey steel structure model has been considered using ETABS software, which was previously tested during the shaking table tests. The comparison of the structural response has been performed between the numerical and experimental results. High compatibility of the results for the fixed-base steel model between the numerical and experimental analyses has been obtained which proves the effectiveness of the modelling techniques used in the ETABS software. It has also been found that the isolation system is effective in improving the response of the steel structure during earthquake. However, modelling the isolation system using the linear springs is not an accurate technique due to the large differences in the structural responses obtained between the numerical and experimental analyses.
\end{abstract}

\section{INTRODUCTION}

Earthquake is considered as one of the most dangerous phenomenon caused by nature as it led to catastrophic damages in many previous seismic events. Scientists have worked extensively to develop new techniques to decrease the level of damages of buildings exposed to earthquakes or eliminate the damages at all (see, for example, Sołtysik, Falborski \& Jankowski, 2016; Sołtysik, Falborski \& Jankowski, 2017; Miari, Choong \& Jankowski, 2019; Naderpour, Naji, Burkacki \& Jankowski, 2019; Miari, Choong \& Jankowski, 2020). One of the modern techniques to resist the effects of earthquakes is the use of isolation systems (see, for example, Robinson \& Greenbank, 1976; Robinson, 1982; Buckle \& Mayes, 1990; Kelly, 1990; Kelly, 1993; Skinner, Robinson \& McVerry, 1993; Robinson, 1998; Buckle, 2000). Base isolators, such as Lead Rubber Bearings, High Damping Rubber Bearings, and Friction Pendulum Bearings, are widely used in practice in many earthquake-prone regions to mitigate structural vibrations, and consequently minimize the loss of life and property damage during seismic events (see, for example, Nagarajaiah \& Xiaohong, 1996; Nagarajaiah \& Xiaohong, 2000). These systems decrease the damages in buildings during earthquakes by controlling the accelerations and displacements of the vibrating structures through inducing flexibility to their bases. The use of this technique prevents the resonance between the structure and the dominant frequency of the ground motion (see, for example, Booth \& Key, 2006; Chopra, 2012).

In order to get an insight into the mechanical behaviour of base isolation devices, quasistatic or dynamic tests are usually performed. One of the most common procedures for experimentally testing buildings subjected to earthquakes is to test them on a seismic shaking table

DOI: $10.1201 / 9781003132134-9$ 
(see, for example, Falborski \& Jankowski, 2017a). Also, the dynamic behaviour of a structure is often modelled numerically using commercial software (see, for example, Falborski \& Jankowski, 2017b; Falborski, Sołtysik \& Jankowski, 2018; Lasowicz, Falborski \& Jankowski, 2018; Falborski \& Lasowicz, 2019). This facilities the consideration of highly complex problems with less difficulties and budget. In the numerical analysis of buildings, several factors are important, such as the modelling approach and the ground conditions. The ground conditions have a large impact on the response of the structure under a seismic load (see, for example, Lasowicz \& Falborski, 2018; Falborski, 2020, Falborski, 2020, Elwardany, Seleemah, Jankowski \& El-khoriby, 2019).

The aim of this study is to investigate the effectiveness of a simplified base isolation modelling technique using the linear springs since the advanced mathematical models are often difficult to be applied in commercial programs. One-storey steel structure model has been considered using ETABS software, which was previously tested during a seismic table test (see, for example, Falborski \& Jankowski, 2018). The response of the numerical model of the one-storey building has been compared with that of the experimental model intending to validate the numerical model. The steel structure model has been studied with two types of bases, i.e. fixed and isolated bases. Comparison has been performed between these models (with different types of bases) to investigate the effect of the use of isolation system on the response of buildings exposed to earthquake excitations.

\section{EXPERIMENTAL MODEL AND SHAKING TABLE INVESTIGATION}

The experimental study has been conducted for a single-storey steel structure model. This model, consisting of a steel frame and two concrete slabs, is of $1.20 \mathrm{~m}$ height and weights $95.12 \mathrm{~kg}$ (see Figure 1). Rectangular elements made of hollow section elements (RHS $15 \times 15 \times 1.5 \mathrm{~mm}$ ) form a welded steel frame, and the columns have been set on a rectangular plan with a spacing of $0.556 \mathrm{~m}$ in the transverse direction (x-direction) and $0.465 \mathrm{~m}$ in the longitudinal direction (y-direction). Diagonal bracings have also been used in the planes of the sidewalls, which are responsible for counteracting transverse and torsional vibrations. The simulation of the weight of the floor and foundation slabs is presented through two concrete plates $(50 \times 50 \times 7 \mathrm{~cm})$.
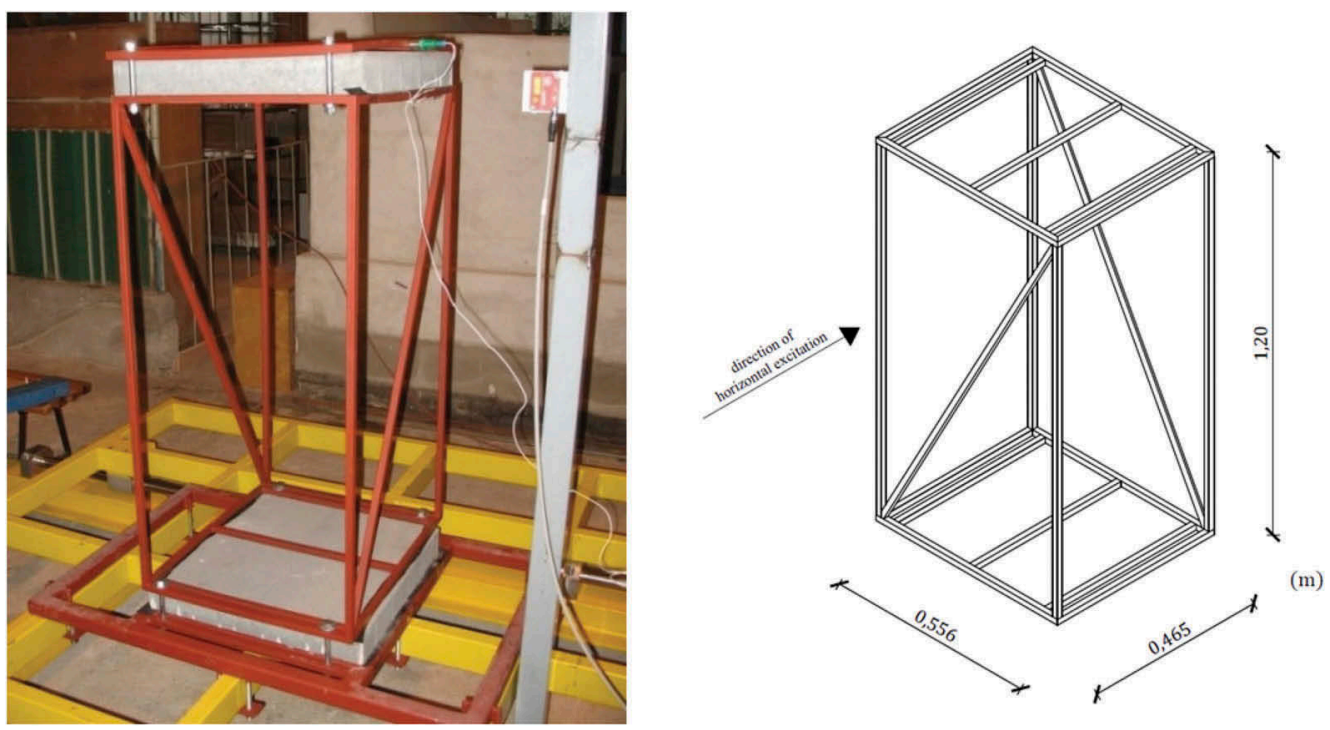

Figure 1. Single-storey steel structure model mounted on the shaking table. 
The dynamic characteristics of the experimental model were previously determined by conducting free vibration tests (see Falborski \& Jankowski, 2017a). The fundamental frequency of the experimental model was calculated to be $3.31 \mathrm{~Hz}$, whereas the damping ratio $0.53 \%$. A middle-sized shaking table located at Gdańsk University of Technology, Poland, was used to investigate the seismic response of the experimental model to a series of earthquake ground motions. All the experimental tests for steel structure models were carried out for a time step size of $0.002 \mathrm{~s}$.

\section{NUMERICAL MODEL}

In this study, single-storey building has been modelled in ETABS software using the Finite Element (FE) method. The slabs have been modelled using shell elements and the beams and columns applying frame elements. The numerical model has been studied first with fixed bases. Then, the same model has been studied with the isolated bases. A simple mathematical model in the form of springs has been introduced in ETABS software. The FE models of both building (with fixed and isolated bases) are shown in Figure 2.

To determine the lateral stiffness $K$ of the springs used, the hysteresis loop at excitation of 2 $\mathrm{Hz}$ has been utilized (see Figure 3). By using this method, the value of the lateral stiffness has been found to be $45 \mathrm{kN} / \mathrm{m}$.

a)

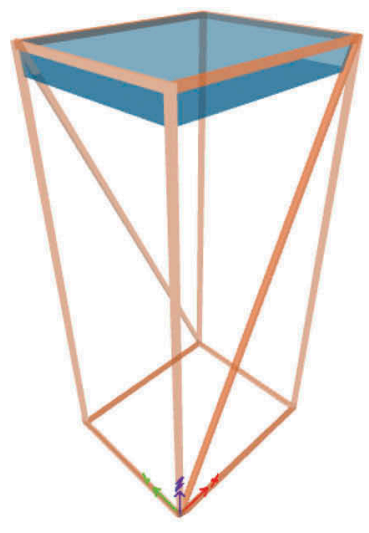

b)

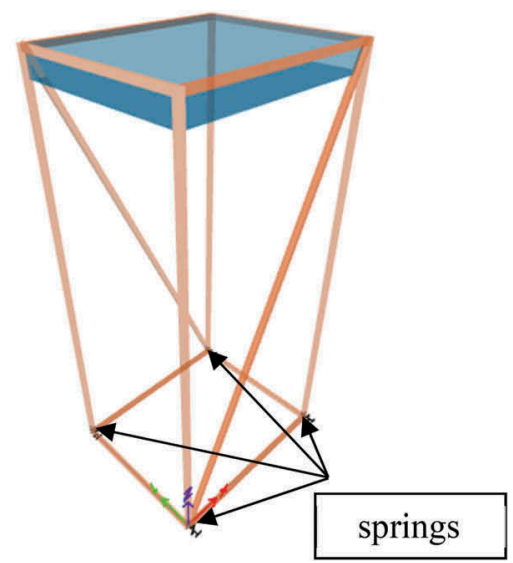

Figure 2. Numerical models of fixed-base building a) and base-isolated building b).

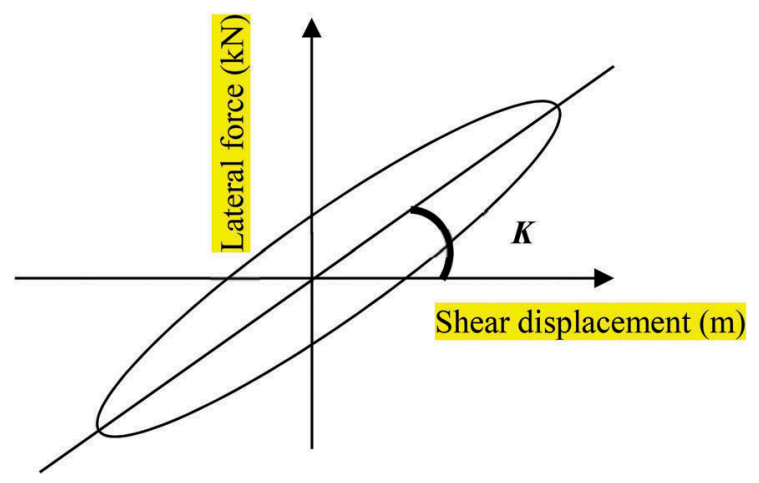

Figure 3. Schematic diagram of a hysteresis loop. 
Table 1. Ground motions used in this study.

\begin{tabular}{llll}
\hline Earthquake & PGA $\left[\mathrm{m} / \mathrm{s}^{2}\right]$ & Station & Year \\
\hline El Centro & 3.070 & Array 9 & 1940 \\
San Fernando & 5.688 & Paicoma Dam & 1971 \\
\hline
\end{tabular}

The detailed numerical analyses have been performed for the described model under two ground motions with different Peak Ground Accelerations (PGA) (see Table 1 for details). The response has been obtained using the linear direct integration method which is based on the Hilbert-Hughes-Taylor method, where the leading parameters are $\gamma=0.5, \beta=0.25$ and $\alpha=0$. The time step size used for the El Centro and San Fernando ground motions has been set at $0.01 \mathrm{~s}$. All the mentioned earthquakes have been properly scaled in the ETABS software to obtain comprehensive comparative analysis.

\section{VALIDATION OF THE NUMERICAL MODEL}

The acceleration time histories computed for the fixed-base model and base-isolated model under various seismic excitations are presented in Figures 4-5. The comparison of the results obtained from the numerical analysis and the shaking table investigation are briefly reported in Table 2 and Table 3. The comparison between the numerical and experimental models for the fixed-base buildings reveals that there is a good agreement between the responses. The difference of the peak acceleration between the numerical and experimental models of the fixedbase building ranges between $4 \%$ and $11 \%$ (see Figure 4 and Table 2). This means that the numerical model is capable of representing the response of the fixed-base building quite accurately. However, the comparison between the acceleration time histories of the numerical and experimental models for the base-isolated buildings reveals that the response is not close and there is no good agreement between them. The difference of the peak acceleration between the

a)

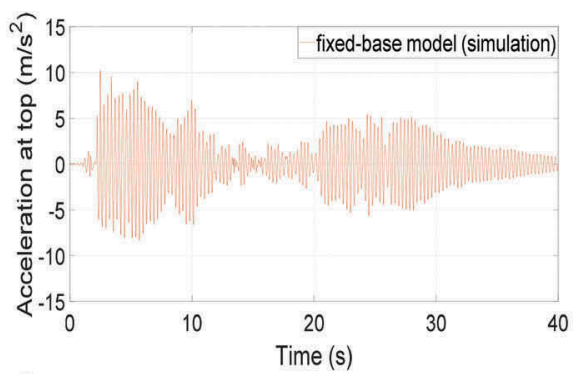

c)

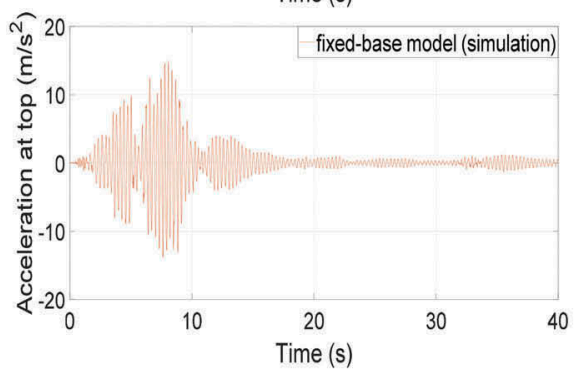

b)

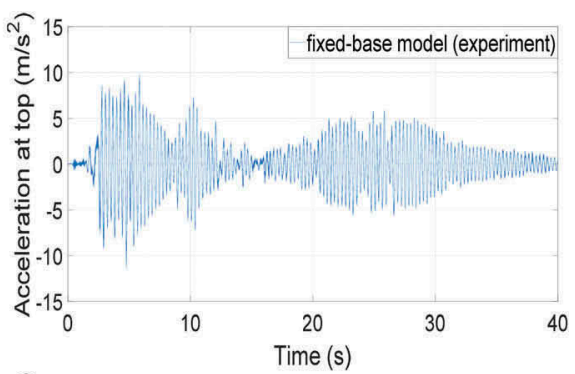

d)

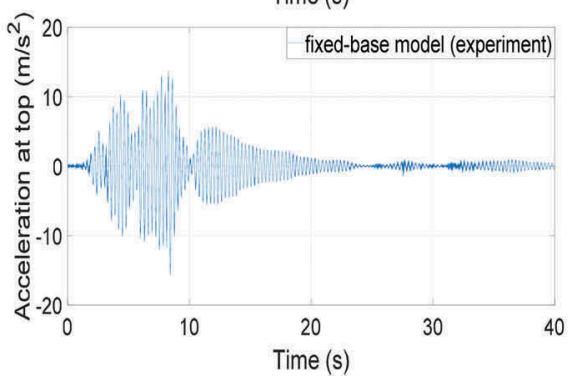

Figure 4. Numerically obtained (left) and experimentally determined (right) time-acceleration history plots for the fixed-base one-storey model during different ground motions: a, b) the 1940 El Centro earthquake and c, d) the 1971 San Fernando earthquake. 
a)

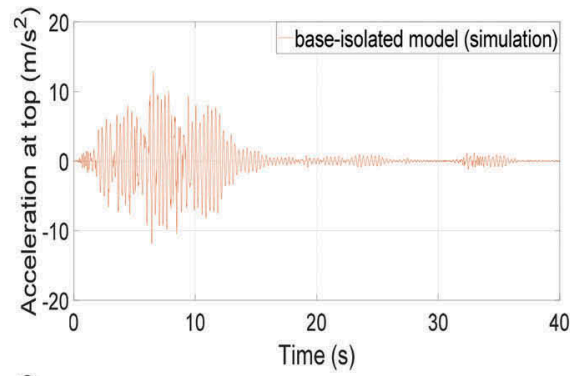

c)

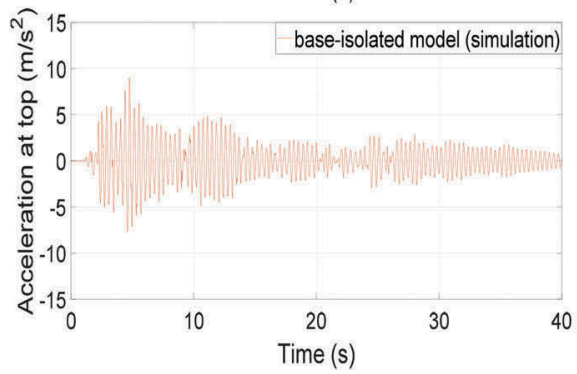

b)

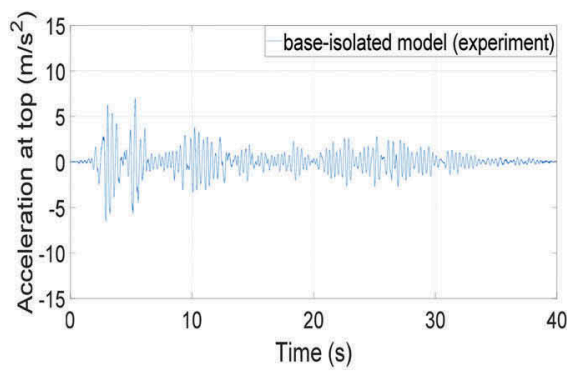

d)

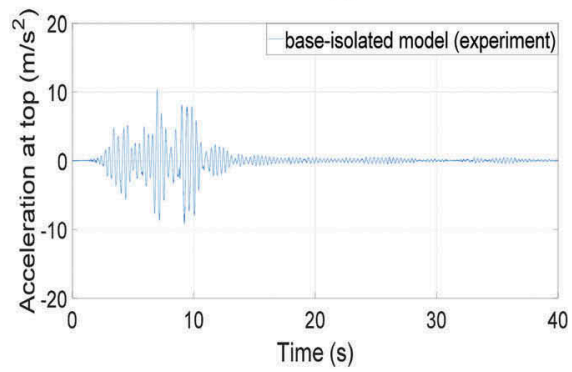

Figure 5. Numerically obtained (left) and experimentally determined (right) time-acceleration history plots for the base-isolated one-storey model during different ground motions: a, b) the 1940 El Centro earthquake and c, d) the 1971 San Fernando earthquake.

Table 2. Results obtained from numerical and experimental investigation for fixed-base model.

\begin{tabular}{llll}
\hline & \multicolumn{2}{l}{$\begin{array}{l}\text { Peak acceleration at the top of the } \\
\text { single-storey steel structure model }\left[\mathrm{m} / \mathrm{s}^{2}\right]\end{array}$} & \\
\cline { 2 - 3 } Dynamic excitation & $\begin{array}{l}\text { Numerical analysis } \\
\text { using ETABS }\end{array}$ & $\begin{array}{l}\text { Shaking table } \\
\text { investigation }\end{array}$ & $\begin{array}{l}\text { Percentage } \\
\text { difference [\%] }\end{array}$ \\
\hline El Centro earthquake & 10.21 & 11.39 & 10.36 \\
San Fernando earthquake & 14.96 & 15.59 & 4.04 \\
\hline
\end{tabular}

Table 3. Results obtained from numerical and experimental investigation for base-isolated model.

\begin{tabular}{lccc}
\hline & \multicolumn{2}{l}{$\begin{array}{l}\text { Peak acceleration at the top of the } \\
\text { single-storey steel structure model }\left[\mathrm{m} / \mathrm{s}^{2}\right]\end{array}$} & \\
\cline { 2 - 3 } Dynamic excitation & $\begin{array}{l}\text { Numerical analysis } \\
\text { using ETABS }\end{array}$ & $\begin{array}{l}\text { Shaking table } \\
\text { investigation }\end{array}$ & $\begin{array}{l}\text { Percentage } \\
\text { difference [\%] }\end{array}$ \\
\hline El Centro earthquake & 9.06 & 6.98 & 22.96 \\
San Fernando earthquake & 12.89 & 10.47 & 18.77 \\
\hline
\end{tabular}

numerical and experimental models of the base-isolated building ranges between $19 \%$ and $23 \%$ (see Figure 5 and Table 3). This means that the numerical model is not capable of representing the response of the base-isolated building. This is referred to the mathematical simplification of the spring model. For more accurate results, more advanced bearing model should be used. 


\section{CONLUSIONS}

This paper has been focused on comparison between the dynamic responses of buildings with fixed and isolated bases exposed to earthquake excitations. One-storey steel structure model has been considered using ETABS software, which was previously tested during the shaking table tests. The main conclusions of this study are:

- High compatibility of the results for the fixed-base steel structure model between the numerical and experimental analyses has been obtained which proves the effectiveness of the modelling techniques used in the ETABS software.

- The use of isolated system is an effective method in improving the response of building exposed to earthquake excitations, as concluded from the results of both experimental and numerical analyses.

- Modelling the isolated system by using the simplified method with linear springs is not an accurate technique due to the large differences in the structural responses found between the numerical and experimental analyses. Therefore, more advanced mathematical models should be used to simulate the behaviour of isolation systems during earthquakes.

\section{REFERENCES}

Booth, E. \& Key, D. 2006. Earthquake Design Practice for Buildings. London: ICE Publishing.

Buckle, I.G. \& Mayes, R.L. 1990. Seismic isolation: History, application, and performance: A world view. Earthquake Spectra 6: 161-201.

Buckle, I.G. 2000. Passive control of structures for seismic loads, Proceedings of the 12th World Conference on Earthquake Engineering 2825: 1-8.

Chopra, A.K. 2012. Dynamics of Structures: Theory and Applications to Earthquake Engineering. New York: Prentice Hall.

Elwardany, H., Seleemah, A., Jankowski, R. \& El-khoriby, S. 2019. Influence of soil-structure interaction on seismic pounding between steel frame buildings considering the effect of infill panels, Bulletin of Earthquake Engineering 17(11): 6165-6202.

Falborski, T. \& Jankowski, R. 2017a. Experimental study on effectiveness of a prototype seismic isolation system made of polymeric bearings. Applied Sciences 7 (8): 808.

Falborski, T. \& Jankowski, R. 2017b. Numerical evaluation of dynamic response of a steel structure model under various seismic excitations. Procedia Engineering 172: 277-283.

Falborski, T. \& Jankowski, R. 2018. Advanced hysteretic model of a prototype seismic isolation system made of polymeric bearings. Applied Sciences 8 (3): 400.

Falborski, T. \& Lasowicz, N. 2019. Numerical investigation on dynamic response of a steel lattice tower under various seismic events, 13th International Conference: Modern Building Materials, Structures and Techniques., 16-18 May 2017.

Falborski, T. 2020. Evaluation of foundation input motions based on kinematic interaction models. In: Köber D., De Stefano M., Zembaty Z. (eds), Seismic Behaviour and Design of Irregular and Complex Civil Structures III. Geotechnical, Geological and Earthquake Engineering, Vol 48. Cham: Springer.

Falborski, T. 2020. Numerical study on seismic response of a high-rise RC irregular residential building considering soil-structure interaction. In: Köber, D., De Stefano, M., Zembaty, Z. (eds), Seismic Behaviour and Design of Irregular and Complex Civil Structures III. Geotechnical, Geological and Earthquake Engineering, Vol 48. Cham: Springer.

Falborski, T., Sołtysik, B. \& Jankowski, R. 2018. Numerical investigation on dynamic performance of a multi-storey steel structure model and comparison with experimental results. Dynamical Systems in Applications, Springer Proceedings in Mathematics and Statistics 249: 105-113.

Kelly J.M., 1993. Earthquake-Resistant Design with Rubber. New York: Springer-Verlag.

Kelly, J.M. 1990. Base isolation: Linear theory and design. Earthquake Spectra 6: 223-244.

Lasowicz, N. \& Falborski, T. 2018. Soil-structure interaction effects on modal parameters of office buildings with different number of stories. MATEC Web of Conferences 219 (8): 03001.

Lasowicz, N., Falborski, T. \& Jankowski, R. 2018. Analysis of temporary steel grandstand with different bracing systems exposed to crowd load. Journal of Measurements in Engineering 6 (4): 256-262. 
Miari, M., Choong, K. K. \& Jankowski, R. 2019. Seismic pounding between adjacent buildings: Identification of parameters, soil interaction issues and mitigation measures. Soil Dynamics and Earthquake Engineering 121: 135-150.

Miari, M., Choong, K.K. \& Jankowski, R. 2020. Seismic pounding between bridge segments: a state-ofthe-art review. Archives of Computational Methods in Engineering DOI: 10.1007/s11831-019-09389-x (published online 13. 01.2020).

Naderpour, H., Naji, N., Burkacki, D. \& Jankowski, R. 2019. Seismic response of high-rise buildings equipped with base isolation and non-traditional tuned mass dampers. Applied Sciences 9(6): 1201.

Nagarajaiah, S. \& Xiaohong, S. 1996. Seismic performance of base-isolated buildings in the 1994 Northridge earthquake. In Proceedings of the 11thWorld Conference on Earthquake Engineering, Acapulco, Mexico, 23-28 June 1996.

Nagarajaiah, S. \& Xiaohong, S. 2000. Response of base-isolated USC hospital building in Northridge earthquake. Journal of Structural Engineering 126: 1177-1188.

Robinson, W.H. \& Greenbank, L.R. 1976. An extrusion energy absorber suitable for the protection of structures during an earthquake. Earthquake Engineering \& Structural Dynamics 4: 251-259.

Robinson, W.H. 1982. Lead-rubber hysteretic bearings suitable for protecting structures during earthquakes. Earthquake Engineering and Structural Dynamics, 10: 593-604.

Robinson, W.H. 1998. Passive control of structures, The New Zealand experience. Journal of Earthquake Technology 35: 63-75.

Skinner, R.I., Robinson, W.H. \& McVerry, G.H. 1993. An Introduction to Seismic Isolation. New York: Wiley.

Sołtysik, B., Falborski, T. \& Jankowski, R. 2016. Investigation on damage-involved structural response of colliding steel structures during ground motions. Key Engineering Materials 713: 26-29.

Sołtysik, B., Falborski, T. \& Jankowski, R. 2017. Preventing of earthquake-induced pounding between steel structures by using polymer elements - experimental study. Procedia Engineering 199: 278-283. 